ROBERT MAJKUT

Wyższa Szkoła Bankowa we Wrocławiu, Polska - WSB University in Wroclaw, Poland

\title{
Charakterystyka uwarunkowań instytucjonalnych wspierania innowacyjności w Austrii ze szczególnym uwzględnieniem systemu edukacyjnego
}

\section{Characteristics of the institutional conditions for innovation support in Austria with a focus on the educational system}

\begin{abstract}
Streszczenie: Artykuł wpisuje się w obszar badań nad innowacyjnością. Jego celem jest dyskusja nad tezą zakładającą, że efektywność funkcjonowania systemu wsparcia innowacyjności w Austrii wynika $\mathrm{z}$ organizacji systemu edukacyjnego i przede wszystkim z organizacji systemu instytucjonalnego wsparcia innowacyjności. Uzasadnieniem celu jest odwołanie się do rankingów innowacyjności gospodarek, według których Austria jest liderem w kluczowej z punktu widzenia innowacyjności kategorii, czyli współpracy biznesu z nauką. Zawarte w artykule ustalenia wynikające z wtórnej analizy danych i materiałów źródłowych wskazują, że efektywność systemu wsparcia innowacji przedsiębiorstw w Austrii wynika z dużych nakładów pieniężnych na inwestycje w badania i rozwój, promocji uczenia się przez całe życie, dużej świadomości roli branży kreatywnej w pobudzaniu innowacyjności, zaangażowania podmiotów austriackich w projekty badawczo-rozwojowe, przejrzystego systemu instytucjonalnego wsparcia innowacyjności koordynowanego przez Austriacką Federalną Izbę Gospodarczą. Innowacyjności sprzyja także zaangażowanie się państwa w jej promocję, a przede wszystkim - pobudzanie innowacyjności firm przez nawiązywanie współpracy przedsiębiorstw z instytucjami naukowo-badawczymi.
\end{abstract}

\begin{abstract}
The article is part of the research on innovation. Its aim is to discuss the thesis assuming that the effectiveness of the functioning of the innovation support system in Austria results from the organisation of the educational system and, above all, from the organisation of the institutional innovation support system. The justification of the objective is to refer to the innovation rankings of economies according to which Austria is the leader in the key category from the point of view of innovation, i.e. cooperation between business and science. The findings of the paper, resulting from the secondary analysis of the data and source materials, indicate that the effectiveness of the system of innovation support for enterprises in Austria is due to the large amount of money invested in research and development, the promotion of lifelong learning, the high awareness of the role of the creative industry in stimulating
\end{abstract}


innovation, the involvement of Austrian entities in research and development projects, the transparent institutional system of innovation support coordinated by the Austrian Federal Economic Chamber. Innovation is also fostered by the state's involvement in promoting innovation and, above all, stimulating the innovativeness of companies by establishing cooperation between companies and scientific and research institutions.

Słowa kluczowe: edukacja; innowacje; innowacyjność; instytucje wsparcia innowacyjności; współpraca przedsiębiorstw $\mathrm{z}$ instytucjami nauki

Keywords: cooperation of enterprises with science institutions; education; innovation; innovativeness; institutions supporting innovativeness

Otrzymano: 11 kwietnia 2021

Received: 11 April 2021

Zaakceptowano: 25 maja 2021

Accepted: 25 May 2021

\section{Sugerowana cytacja/Suggested citation:}

Majkut, R. (2021). Charakterystyka uwarunkowań instytucjonalnych wspierania innowacyjności w Austrii ze szczególnym uwzględnieniem systemu edukacyjnego. Przedsiębiorczość - Edukacja [Entrepreneurship - Education], 17(1), 104-114. https://doi.org/10.24917/20833296.171.8

\section{Wstęp}

Obserwowane $\mathrm{w}$ świecie przemiany wymuszają na przedsiębiorcach uruchomienie działań, które pozwalają ich przedsiębiorstwom nie tylko funkcjonować na dynamicznie zmieniającym się rynku, ale także się rozwijać. Wśród licznych czynników przedsiębiorczości współcześnie na czoło wysuwa się innowacyjność.

Waga innowacyjności przedsiębiorstw jest dostrzegana zarówno na gruncie literatury fachowej, jak i w opracowaniach publicystycznych oraz pracach o charakterze implementacyjnym. Względnie obszerna literatura przedmiotu nie jest jednak wyczerpująca w tym względzie i ma istotne braki. Niniejszy artykuł wpisuje się w obszar badań nad innowacyjnością i uzupełnia braki poznawcze oraz praktyczne. Jego celem jest dyskusja nad tezą zakładającą, że efektywność funkcjonowania systemu wsparcia innowacyjności w Austrii wynika z organizacji systemu edukacyjnego, a przede wszystkim - z organizacji systemu instytucjonalnego wsparcia innowacyjności. Cel ten jest uzasadniony wysoką pozycją gospodarki i przedsiębiorstw austriackich w rankingach innowacyjności gospodarek oraz pozycją lidera w kluczowej z punktu widzenia innowacyjności kategorii, czyli współpracy biznesu z nauką, którą Austria zajmuje w Europejskim Rankingu Innowacyjności za rok 2019 (Ranking innowacyjności 2019, 2021, 21 lutego). Z tej przyczyny zawarte w artykule ustalenia stanowiące realizację przyjętego celu mogą być pomocne przy opracowywaniu w innych krajach (przede wszystkim w Polsce) programów, których zadaniem będzie intensyfikacja działań na rzecz integracji przedsiębiorców z przedstawicielami świata nauki w celu zwiększenia poziomu innowacyjności firm.

Artykuł powstał we współpracy z Konsulatem Honorowym Austrii w Polsce, a dla potrzeb osiągnięcia założonego w artykule celu wykorzystano przede wszystkim wtórną analizę danych i materiałów źródłowych. 


\section{Poziom innowacyjności przedsiębiorstw w Austrii}

Zagadnienia innowacji i innowacyjności należy odnieść do dziedziny zarządzania, traktując innowacje jako czynnik rozwoju przedsiębiorstwa czy przedsiębiorczości w ogóle. Pojęcie innowacji jest używane przez przedstawicieli wielu nauk, przez co nie istnieje jego jedna uniwersalna definicja (Prystrom, 2012).Termin „innowacja” wywodzi się od łacińskich słów innovare albo innovatio. Pierwsze z nich oznacza 'odświeżać', 'odnawiać', natomiast drugie - 'odnowienie' (Kalinowski, 2010: 13). Między „innowacjami” a „innowacyjnością” istnieje ścisła relacja. Za A.H. Jasińskim można stwierdzić, że innowacyjność to wykorzystywanie z sukcesem nowych pomysłów (Jasiński, 2014). Istotą innowacyjności jest selektywne poszukiwanie i wdrażanie innowacji na gruncie walki konkurencyjnej między podmiotami gospodarczymi o zwiększenie udziałów w rynku.

Ogólnie gospodarka Austrii w rankingach innowacyjności plasuje się powyżej średniej Unii Europejskiej, co wynika z wysokiego udziału przedsiębiorstw innowacyjnych. W latach 2016-2018 63\% przedsiębiorstw działających w Austrii można było określić jako aktywne w innowacjach. W 2018 roku innowacje produktowe wygenerowały 14,9\% całkowitej sprzedaży przedsiębiorstw w Austrii. Innowacje rynkowe w tym okresie stanowiły $6,3 \%$ całkowitej sprzedaży. W przypadku innowacji rynkowych $8,6 \%$ stanowiły produkty, które nie były nowością na rynku, ale były nowe dla firmy. W latach 20162018 23\% austriackich przedsiębiorstw wprowadziło co najmniej jedną nowość rynkową, a w 55\% firm wprowadzono nowe lub ulepszone procesy biznesowe, dotyczące wytwarzania towarów lub usług, procedur logistycznych, prowadzenia ksiąg rachunkowych, metod organizacji procesów biznesowych lub relacji zewnętrznych ze stronami trzecimi, metod organizacji pracy, podejmowania decyzji lub zarządzania zasobami ludzkimi, a także metod marketingowych (Die WKO-Innovationsstrategie für Österreich, 2020).

W świetle wyników badań dotyczących innowacyjności przedsiębiorstw austriackich można stwierdzić, że dużą aktywność innowacyjną do 2018 roku wykazywały przedsiębiorstwa $\mathrm{z}$ sektora chemicznego, przede wszystkim zajmujące się produkcją farmaceutyczną. Spośród nich innowacyjnych było 56\%. Odsetek ten wyższy był w przedsiębiorstwach zajmujących się inżynierią mechaniczną i budową pojazdów, gdzie wyniósł on $77 \%$. Jeszcze więcej innowacyjnych firm, bo $87 \%$, stanowiły przedsiębiorstwa produkujące sprzęt komputerowy. Wysoki udział przedsiębiorstw innowacyjnych widoczny był także w sektorze usług telekomunikacyjnych i teleinformatycznych. W tym obszarze ponad 80\% firm w 2018 r. było aktywnych we wdrażaniu innowacji (Die WKO-Innovationsstrategie für Österreich, 2020). W 2020 r. w Austriackim Urzędzie Patentowym złożono 2297 wniosków patentowych i udzielono 1058 praw patentowych. Tym samym liczba zgłoszeń patentowych wzrosła w stosunku do roku 2019, w którym zgłoszono 2274 wnioski patentowe, z czego przyznano 1112 praw patentowych. W roku 2018 zgłoszono 2207 wniosków, z czego prawa patentowe uzyskano w 1189 przypadkach. Natomiast wydatki na badania i rozwój w Austrii w 2020 r. szacowane były na ok. 12,1 mld euro, porównywalnie jak w roku 2018, ale mniej niż w 2019 r., w którym te nakłady wyniosły 12,69 mld euro (Anzahl der Patentanmeldungen und-erteilungen..., 2021, 20 maja).

Gospodarka Austrii, podobnie jak gospodarka Polski, oparta jest na mikro-, małych i średnich przedsiębiorstwach (MMŚP). W 2018 r. austriackie przedsiębiorstwa z tego sektora na innowacje przeznaczyły ok. 9,8 mld euro. 83\% tych wydatków na innowacje wydano na badania i rozwój $(B+R)$, a $17 \%$ na inne działania, takie jak zakup maszyn lub 
wiedzy zewnętrznej, a także na szkolenia lub prace projektowe w zakresie innowacji. 18\% wszystkich firm współpracowało z innymi firmami lub instytucjami w swoich działaniach innowacyjnych. Partnerami do współpracy w zakresie innowacji były najczęściej uniwersytety, politechniki lub inne uczelnie wyższe. $Z$ tego typu instytucjami współpracowało 61\% przedsiębiorstw (Innovation im Unternehmenssektor, 2021, 21 lutego).

\section{Organizacja systemu szkolnego jako czynnik innowacyjności Austrii}

System edukacyjny w Austrii odgrywa w tym kraju ważną rolę przygotowującą do funkcjonowania w innowacyjnej gospodarce. System szkolnictwa w Austrii pozostaje pod nadzorem państwa i można uznać, że jest dość skomplikowany, ale przyświeca mu idea dopasowania trybu edukacyjnego do kompetencji danej osoby, dość wszechstronny rozwój oparty na nauce zarówno przedmiotów humanistycznych, jak i ścisłych, z naciskiem na rozumienie i wyjaśnienie zagadnień wraz z umiejętnością samodzielnego szukania wiedzy. Poza tym system ten wyróżnia:

1. stabilność,

2. nacisk na przedmioty praktyczne oraz naukę zawodu w ramach systemu dualnego,

3. funkcjonowanie znacznej liczby rodzajów ścieżek kształcenia i możliwości kombinacji wyboru różnych typów szkół.

W Austrii obowiązek szkolny zaczyna się od szóstego roku życia, a kończy po dziewięciu latach nauki. Oprócz szkół publicznych dostępne są także szkoły prywatne występujące praktycznie na każdym etapie kształcenia. Pierwszym etapem nauki jest nauka przedszkolna, obejmująca dzieci w wieku 3-6 lat. Kolejnym etapem jest Vorschule, której głównym zadaniem jest przygotowanie dzieci do nauki w szkole. Po tym etapie rozpoczyna się etap obowiązkowego kształcenia podstawowego, na który składają się oprócz nauki czytania, pisania, liczenia oraz, co niezwykle istotne z punktu widzenia gospodarki opartej na wiedzy i innowacyjności, umiejętność szukania i przetwarzania informacji. Austria posiada specyficzny system szkolnictwa po szkole podstawowej. Po jej zakończeniu uczniowie mogą wybrać średnią szkołę ogólnokształcącą lub szkołę tzw. główną. Wybór szkoły następuje po określeniu zdolności ucznia i ustaleniu drogi dalszej edukacji. Kształcenie na tym etapie trwa 4 lata. W szkole głównej można otrzymać gruntowne wykształcenie przygotowujące do nauki w szkołach wyższych. Uczniowie mogą dodatkowo rozwijać tu swoje zainteresowania i umiejętności praktyczne. Relatywnie nowym rozwiązaniem w Austrii są szkoły Kooperative Mittelschule (KMS), utworzone na podstawie programu szkoły głównej. W KMS znaczną wagę przykłada się do indywidualnych zdolności i umiejętności poszczególnych uczniów. Duża część uczniów po szkole podstawowej wybiera Allgemeinbildende Höhere Schule (AHS), czyli średnią szkołę ogólnokształcącą, co wymaga jednak uzyskania określonych dobrych lub bardzo dobrych ocen w nauce w szkole podstawowej, głównie z języka niemieckiego i matematyki. Do wyboru są tutaj cztery rodzaje placówek edukacyjnych: 1) Gymnasium, które oferuje przede wszystkim gruntowne humanistyczne wykształcenie ogólne z łaciną i greką (fakultatywnie), przy czym te drugie zajęcia coraz częściej zastępowane są przez naukę francuskiego, włoskiego lub hiszpańskiego; 2) Realgymnasium, przeznaczone dla uczniów uzdolnionych w dziedzinie nauk przyrodniczych; 3) Wirtschaftskundliches Realgymnasium, zawierające $\mathrm{w}$ swym programie zagadnienia związane $\mathrm{z}$ gospodarką; 4) Oberstufengymnasium, oferujące zajęcia związane przede wszystkim ze sztuką 
i przyrodą. Nauka w tych szkołach kończy się egzaminem maturalnym. W austriackim systemie edukacyjnym funkcjonują także technika (Berufsbildende Höhere Schulen BHS), do których można uczęszczać po 8 latach nauki. Opierają się one na 5 latach nauki i dają szansę nie tylko zdobycia wykształcenia zawodowego, lecz także zdania egzaminu maturalnego. Część BHS pozwala zdobyć wykształcenie w 3 lata. Wówczas edukacja nie kończy się egzaminem maturalnym. Wśród średnich szkół technicznych w Austrii wyróżnić można technika specjalistyczne, na które składają się m.in.: Technische Lehranstalten (HTL), oferujące przede wszystkim możliwość zdobycia technicznego wykształcenia zawodowego, oraz Handelsakademie, w których mocnymi punktami są rachunkowość i ekonomika przedsiębiorstw. Specyficznym rodzajem placówek edukacyjnych są szkoły HBLA, czyli Höhere Bundeslehranstalt. Są one podobne profilowo do HTL, ale nie są zorientowane technicznie. Nauka w nich trwa 5 lat.

W ramach austriackiego systemu kształcenia znajdujemy również Polytechnische Schulen, czyli szkoły politechniczne wybierane przede wszystkim przez uczniów, którzy chcą przed zakończeniem obowiązku szkolnego zdobyć zawód. Obok nich są do wyboru Berufsschulen, czyli szkoły zawodowe, w których okres nauki obejmuje 2-3 lata. W systemie istnieją również instytucje Postsekundäre Bildung, czyli szkoły policealne, takie jak kolegia i akademie. Czas trwania nauki jest w tych instytucjach krótszy niż w uczelniach wyższych. Oprócz tego są także kolegia przeznaczone dla absolwentów AHS i oferujące zdobycie wykształcenia technicznego w czasie krótszym niż na uniwersytecie. Charakterystyczny jest tu luźny obowiązek uczestnictwa w zajęciach, elastyczne są także terminy zaliczeń i egzaminów. W akademiach natomiast stanowiących tzw. krótkie studia otrzymuje się specyficzne wykształcenie zawodowe, najczęściej z zakresu medycyny, spraw socjalnych lub pedagogiki (Szwankowska-Antol, 2021). Warunkiem koniecznym dostania się do akademii, w której nauka trwa trzy lata, jest zdanie testu lub pozytywne przejście przez rozmowę wstępną.

Austria dysponuje dobrze rozwiniętą siecią uczelni wyższych. Obejmuje ona 21 wyższych szkół zawodowych, 22 uniwersytety publiczne i 13 uniwersytetów prywatnych. Wyższe szkoły zawodowe, oferujące 660 kierunków studiów, są otwarte na potrzeby przedsiębiorstw i utrzymują intensywne kontakty z przemysłem. Około połowy kierunków studiów oferowanych przez wyższe szkoły zawodowe połączonych jest jednocześnie z nauką zawodu (Studia w Austrii, 2021, 21 lutego). Jednak tym, co przede wszystkim wyróżnia system edukacyjny Austrii i w znacznym stopniu przygotowuje kadry do funkcjonowania w nowoczesnej, innowacyjnej gospodarce, jest powiązanie gospodarki z nauką oparte na dualnym kształceniu łączącym teorię z praktyką. Programy nauczania są tu dostosowane do wymogów gospodarki, a ważne miejsce zajmują w nich prace dyplomowe, których ustalenia implementowane są w praktyce działania podmiotów gospodarczych.

Można zatem stwierdzić, że w aspekcie edukacyjnym system w Austrii kładzie duży nacisk na kształtowanie praktycznych kompetencji i umiejętności ważnych w innowacyjnej gospodarce. Zwraca się także uwagę na indywidulane możliwości i preferencje uczniów, a różnorodność form kształcenia wpływa na przygotowanie kadr do wszystkich sektorów gospodarki.

W działaniach na rzecz współpracy biznesu z nauką uwidacznia się rola otoczenia instytucjonalnego wsparcia innowacji. 
Otoczenie instytucjonalne innowacyjności austriackich przedsiębiorstw

Krajowy system instytucjonalny wsparcia innowacji przedsiębiorstw w Austrii oparty jest na działaniach austriackiej Federalnej Izby Gospodarczej (WKÖ - Wirtschaftskammer Österreichs) jako organu centralnego. Natomiast w wymiarze regionalnym w dziewięciu poszczególnych krajach członkowskich funkcjonują Regionalne Izby Gospodarcze (Landeskammer), stanowiące kluczowe elementy regionalnego systemu wsparcia innowacji przedsiębiorstw. Przynależność do Izby Gospodarczej jest obowiązkowa dla każdego przedsiębiorcy. Charakteryzując pokrótce zadania WKÖ, można stwierdzić, że funkcjonująca na poziomie federalnym z oddziałami w każdym kraju związkowym Austriacka Izba Gospodarcza oferuje wiedzę ekspercką dla członków i z tego powodu jest pierwszym punktem kontaktowym dla przedsiębiorców, którzy potrzebują określonych informacji i porad. Członkowie są zobowiązani do wnoszenia składek i mają czynne oraz bierne prawo do głosowania w wyborach zarządu i przedstawicieli do Izby Gospodarczej. Zakres świadczonych usług przez Izby Gospodarcze w Austrii jest szeroki, obejmuje obsługi księgowe, prawne, szkolenia, koordynacje działań na rzecz integracji przedsiębiorstw w grupy, a także działania z zakresu promocji eksportu (Die Wirtschaftskammer Österreich, 2021, 21 lutego).

Nawiązując do zasadniczego celu artykułu, należy stwierdzić, że Federalna Izba Gospodarcza jest instytucją centralną inicjującą, koordynującą i wspierającą działania na rzecz innowacyjności austriackich przedsiębiorstw. Realizowane jest to w takich obszarach, jak:

1. promowanie innowacji. W ramach tego obszaru przedsiębiorstwa mogą za pośrednictwem Izby ubiegać się o fundusze federalne, regionalne, stanowe lub unijne na projekty w zakresie innowacji i technologii. Oprócz tego wsparcia oferowana jest także pomoc merytoryczna w postaci ekspertyz w zakresie programów finansowania innowacji;

2. konsultacje w zakresie pomysłu na innowacje. Korzystając z kwestionariusza Przywództwo dla innowacji, menadżerowie mogą dowiedzieć się, jak bardzo są innowacyjni oraz w których obszarach nadal istnieje możliwość poprawy;

3. wskazywanie trendów i możliwości rynkowych. Wykorzystuje się do tego tzw. „Radar Innowacji” Austriackiej Spółdzielni Badawczej (ACR), która dostarcza informacji na temat aktualności technologicznych i rozwiązań proinnowacyjnych przeznaczonych dla przedsiębiorstw;

4. integracja $\mathrm{z}$ administracją publiczną. Firmy z innowacyjnymi pomysłami dla administracji publicznej mogą prezentować swoje produkty i usługi na internetowej platformie partnerstwa innowacyjnego. Instytucje reprezentujące administrację publiczną przedstawiają tam swoje aktualne problemy i poszukują dostawców innowacyjnych rozwiązań;

5. promowanie przedsiębiorstw z obszaru przemysłu kreatywnego. W tym zakresie Izba promuje, finansuje i pomaga nawiązać współpracę z przedsiębiorstwami reprezentującymi tę branżę;

6. koordynacja działań z obszaru rozwiązań na rzecz rozwoju innowacji. Austriacka Izba Gospodarcza koordynuje współpracę w zakresie badań i rozwoju oraz wspiera firmy w inicjowaniu, planowaniu i realizacji partnerstw, z uwzględnieniem prawnych aspektów umów o współpracy. 
W aspekcie podnoszenia poziomu digitalizacji firm, który stanowi obecnie w Austrii priorytet, Izba Gospodarcza koordynuje doradztwo oraz realizację projektów digitalizacyjnych. W ramach proponowanych programów przedsiębiorstwa mogą ubiegać się o finansowanie doradztwa w formie analizy możliwości wdrożenia innowacji cyfrowych, a następnie - o wsparcie finansowe dla konkretnych projektów podnoszących poziom digitalizacji przedsiębiorstw. W procesie wdrażania innowacji procesowych $\mathrm{w}$ aspekcie digitalizacji wspierane są działania promujące fakturowanie elektroniczne, alokację elektroniczną, bezpieczeństwo IT, bezpieczeństwo danych, E-commerce i sklep internetowy oraz marketing online i w mediach społecznościowych. Tutaj bardzo wyraźnie widać współpracę przedsiębiorstw, głównie z sektora MMŚP, z instytucjami zajmującymi się cyfryzacją, przede wszystkim z uczelniami wyższymi, a także z innymi instytucjami badawczymi (Digital Innovation Hubs, 2021, 21 lutego). W ramach tego realizowany jest program Digital Pro Bootcamps BMDW, którego celem jest kształtowanie kompetentnych kadr przygotowanych do funkcjonowania w innowacyjnej gospodarce cyfrowej. Jednocześnie powstające sieci powiązań firm z uczelniami mają być wykorzystywane do promowania pomysłów na nowe modele biznesowe (Digital Pro Bootcamps, 2021, 21 lutego). W ramach Digital Pro Bootcamps pracownicy austriackich firm na szkoleniach organizowanych przez uniwersytety lub uczelnie techniczne zdobywają wiedzę i umiejętności informatyczne.

Ważne miejsce w krajowym systemie innowacji w Austrii zajmuje Agencja Wspierania Badań Naukowych (FFG). Jest ona instytucją koordynującą oferty finansowania MMŚP w zakresie wejścia na rynek oraz działań badawczych i wdrażania innowacji. Organizacja ta oferuje finansowanie innowacji, a także, w ramach programu Przemysł 4.0, zapewnia szereg dotacji na analizy i prace koncepcyjne, inwestycje w nowoczesny sprzęt oraz szkolenia dla pracowników. Wsparcie obejmuje analizę możliwych do przeprowadzenia innowacji procesowych oraz transformacji cyfrowej przedsiębiorstw MMŚP. Działania te są wzmacniane przez rozwiązania służące znalezieniu nowych firm jako partnerów do współpracy. W tym celu zorganizowana została platforma internetowa aws Connect (https://www. awsconnect.at). Agencja tworzy m.in. programy podstawowe, stanowiące najważniejsze narzędzie polityki innowacji dla MMŚP. W ich ramach oferowane jest finansowanie wszelkich przedsięwzięć innowacyjnych, także realizowanych we współpracy z firmami, instytutami badawczymi i uczelniami. Dofinansowanie wynosi zazwyczaj 50\% kosztów projektu, a w połączeniu dotacji z pożyczką może wzrosnąć nawet do 70\%. Okres finansowania wynosi zwykle rok (Basisprogramm - Förderung, Bedingungen, 2021, 21 lutego).

Oprócz wskazanych powyżej programów Agencja Wspierania Badań Naukowych oferuje szereg innych form pomocy, takich jak Impact Innovation Programme (Impact Innovation - Förderung, Bedingungen, 2021, 21 lutego), stanowiący wsparcie MMŚP w rozwijaniu innowacyjnych pomysłów i rozwiązań, które stanowią wartość dodaną w stosunku do istniejącej oferty, czy też tak zwane Laboratorium Pomysłów FFG (Ideas Lab 4.0), które skupia się na łączeniu nowych partnerów. Laboratorium Pomysłów to interaktywne warsztaty, podczas których w ciągu kilku dni przedstawiciele różnych branż i organizacji pracują nad innowacyjnym podejściem do konkretnego problemu. Rezultatem są wnioski projektowe, które są przedstawiane na zakończenie Ideas Lab i oceniane przez międzynarodowe jury (Ideen Lab 4.0., 2021, 21 lutego).

Warto także zwrócić uwagę na popularne w Austrii rozwiązanie proinnowacyjne, jakim jest czek innowacyjny z możliwością odliczenia. Przedsiębiorstwa z sektora MMŚP, 
które chcą rozpocząć działalność badawczą i innowacyjną $(B+R+I)$ lub pogłębić swoją działalność $\mathrm{w}$ zakresie $\mathrm{B}+\mathrm{R}+\mathrm{I}$, a także skorzystać $\mathrm{z}$ wiedzy oraz doświadczeń instytucji badawczych, mogą ubiegać się o finansowanie w wysokości do 10000 euro (Innovationsscheck mit Selbstbehalt, 2021, 21 lutego). Działalność badawczo-rozwojowa przedsiębiorstw w Austrii wspierana jest także przez premię naukową. Przyczynia się ona w istotny sposób do zwiększenia atrakcyjności Austrii jako miejsca prowadzenia badań, których rezultaty mogą pozytywnie wpływać na podniesienie poziomu innowacyjności przedsiębiorstw. Można się o nią ubiegać w ramach badań własnych oraz w ramach badań prowadzonych we współpracy z innym podmiotem. Wysokość premii za badania naukowe jest taka sama dla wszystkich przedsiębiorstw bez względu na ich wielkość czy też wyniki ekonomiczne. W Austrii w obszarze działań wspierających innowacyjność gospodarki i przedsiębiorstw dąży się do zwiększenia współpracy między nauką lub badaniami podstawowymi a przedsiębiorstwami. Służyć temu mają takie działania, jak obsługa wspólnych projektów badawczo-rozwojowych oraz regularne konsultacje przedsiębiorców z instytucjami naukowymi i badawczymi. Celem jest tutaj zwiększenie poziomu innowacji poprzez określenie wymagań rynku i przede wszystkim szybkie udostępnianie wiedzy naukowej i technologicznej dla wykorzystywania jej w działalności operacyjnej firm. Dzięki temu można osiągnąć przewagę konkurencyjną, wynikającą z posiadania patentów, wczesnej penetracji rynku i osiągnięcia pozycji przedsiębiorstwa - lidera innowacji. Koordynatorem w tym procesie jest Izba Gospodarcza, która udostępnia bazy danych infrastruktury badawczej i wytyczne dotyczące współpracy, a także służy pomocą w znalezieniu organizacji partnerskich wśród instytucji nauki wraz z agencjami finansującymi i klastrami, współpracując w tym względzie z Funduszem na rzecz Wspierania Badań Naukowych (Der Wissenschaftsfonds - FWF). Organizacja ta zajmuje ważne miejsce w relacjach świata biznesu ze światem nauki w Austrii. Jest ona centralną austriacką instytucją zajmującą się promocją badań podstawowych. Misją tej instytucji jest „wspieranie rozwoju nauki na wysokim międzynarodowym poziomie, a także przyczynianie się do rozwoju kulturalnego, do ekspansji społeczeństwa opartego na wiedzy, a tym samym do zwiększania dobrobytu w Austrii” (FWF Der Wissenschaftsfonds, 2021, 21 lutego). Działalność FWF ma na celu zwiększenie atrakcyjności Austrii jako lokalizacji naukowej, przede wszystkim przez promowanie badań naukowych, a także przez przyczynianie się do poprawy konkurencyjności instytucji badawczych i systemu nauki. Poza tym instytucja ta ma na celu ułatwianie komunikacji i rozszerzenie interakcji między nauką a wszystkimi innymi instytucjami życia kulturalnego, gospodarczego i społecznego. Działa także na rzecz promocji badań naukowych (Portal FWF, 2021, 21 lutego). Usługi oferowane przez FWF obejmują kompleksowe zarządzanie programem badań, w ramach którego ma miejsce także wybór ekspertów naukowych.

Istotna jest również rozwijana w Austrii koncepcja tworzenia stref innowacji (Die WKO-Innovationsstrategie für Österreich, 2020). Strefa innowacji to ograniczony przestrzennie obszar, na którym działalność przedsiębiorstw jest skoordynowana ze specyfiką danego regionu pod względem zapotrzebowania na innowacje i potencjał naukowo-badawczy oraz system prawny.

Wśród działań o charakterze motywacyjnym, których celem jest kształtowanie postaw proinnowacyjnych, w Austrii Federalne Ministerstwo Cyfryzacji i Rozwoju Przedsiębiorczości (das Bundesministerium für Digitalisierung und Wirtschaftsstandort - BMDW) przyznaje państwową nagrodę za innowacje (Staatspreis Innovation, 2021, 21 lutego). 
Ma ona już dość długą tradycję, ponieważ pierwszą nagrodę przyznano w 1979 r. Procedura wyboru najbardziej innowacyjnej firmy oparta jest na konkursach regionalnych. Przedsiębiorstwa, które w poszczególnych krajach związkowych Austrii zostają uznane za najbardziej innowacyjne, są oceniane przez komisję centralną z ramienia Austriackiego Stowarzyszenia na rzecz Wsparcia Gospodarczego (Austria Wirtschaftsservice Gesellschaft - AWS). Oprócz nagrody głównej w konkursie przyznawane są nagrody specjalne. Należą do nich nagroda ECONOVIUS, która jest przyznawana najbardziej innowacyjnym mikro-, małym lub średnim przedsiębiorstwom, oraz „VERENA powered by VERBUND” przyznawana firmom, które wraz z uczelniami lub pozauniwersyteckimi instytucjami badawczymi zrealizowały projekty innowacyjne w obszarach efektywności zarządzania energią, odnawialnych źródeł energii, e-mobilności i systemów energetycznych. W konkursie mogą uczestniczyć austriackie firmy, które opracowały innowacyjne produkty, procesy lub usługi i wprowadziły je na rynek (Portal Staatpreis Innovation, 2021, 21 lutego). Zwycięzcy otrzymują nagrody pieniężne, a wszyscy nominowani do nagrody uzyskują certyfikaty i mogą liczyć na szeroko zakrojoną promocję.

\section{Podsumowanie}

System instytucjonalnego wsparcia innowacji przedsiębiorstw w Austrii charakteryzuje się określonymi atrybutami, ale także ma swoje słabości. Jego słabymi stronami są mimo wszystko, patrząc na rankingi międzynarodowe, dość małe efekty w stosunku do wysokich nakładów na badania i rozwój oraz rozbudowane wsparcie oparte na triadzie biznes - nauka - administracja publiczna (Die WKO-Innovationsstrategie für Österreich, 2020). Natomiast cechami decydującymi ow efektywności sytemu wsparcia innowacji przedsiębiorstw w Austrii są: duże nakłady finansowe na inwestycje w badania i rozwój, ugruntowana kultura współpracy między nauką a przemysłem, duża liczba innowacyjnych mikro-, małych i średnich przedsiębiorstw, kultura kształcenia ze szczególnym uwzględnieniem kształcenia dualnego oraz na podstawie indywidualnych predyspozycji, promocja uczenia się przez całe życie, wysoka świadomość roli branży kreatywnej w pobudzaniu innowacji przedsiębiorstw, świadomość wkładu nowych form współpracy w ramach strategii otwartych innowacji, dostęp do kapitału w finansowaniu kredytowym dla MMŚP, ponadprzeciętne zaangażowanie podmiotów austriackich w projekty badawczo-rozwojowe, dość klarowny system instytucjonalny z instytucją koordynującą działania na rzecz podnoszenia innowacyjności gospodarki i przedsiębiorstw w postaci Austriackiej Federalnej Izby Gospodarczej, a także znaczne zaangażowanie się państwa w promocję innowacyjności. Istotne jest również pobudzanie innowacyjności firm przez nawiązywanie współpracy przedsiębiorstw z instytucjami naukowo-badawczymi i instytucjami administracji publicznej.

Omówione w artykule obserwowane w Austrii czynniki wspierania innowacyjności przedsiębiorstw pozwalają pozytywnie zweryfikować postawioną hipotezę badawczą, zgodnie z którą efektywność działań proinnowacyjnych zależy od organizacji systemu edukacyjnego oraz rozwiązań instytucjonalnych, które wymagają zaawansowanej koordynacji, a także integracji środowiska naukowego z przedsiębiorcami. Ważne są także instrumenty promowania i nagradzania działań o charakterze innowacyjnym. Jednak to, co szczególnie warto pokreślić, analizując system wsparcia innowacji przedsiębiorstw na przykładzie Austrii, to kształtowanie postaw społecznych, które oparte są na kreatywności 
i w konsekwencji służą tworzeniu innowacji. Bardzo ważną rolę odgrywa w tym systemie nie tylko określona polityka gospodarcza państwa, ale też, co zostało podkreślone w artykule, organizacja i stabilność systemu edukacyjnego przygotowującego do elastycznego podejścia do różnych form i etapów kształcenia uwzględniających indywidualne predyspozycje i kompetencje, a w konsekwencji przygotowującego do funkcjonowania w złożonych i zmiennych warunkach otoczenia.

\section{Literatura}

\section{References}

Anzahl der Patentanmeldungen und -erteilungen in Österreich von 2012 bis 2020. (2021, 20 maja). Pozyskano z: https://de.statista.com/statistik/daten/studie/305660/umfrage/patentanmeldungen -und-erteilungen-in-oesterreich/

Basisprogramm - Förderung, Bedingungen. (2021, 21 lutego). Pozyskano z: https://www.ffg.at/programm/basisprogramm

Die Wirtschaftskammer Österreich. (2021, 21 lutego). Pozyskano z: https://www.wko.at/service/oe/ wirtschaftskammer.html

Die WKO-Innovationsstrategie für Österreich. (2020). Pozyskano z: https://www.wko.at/site/innovate-austria/innovationsstrategie/wko-innovationsstrategie.pdf

Digital Innovation Hubs. (2021, 21 lutego). https://www.ffg.at/dih

Digital Pro Bootcamps. (2021, 21 lutego). https://www.bmdw.gv.at/Themen/WirtschaftsstandortOesterreich/KMU/Digital-Pro-Bootcamps.html

FWF Der Wissenschaftsfonds. (2021, 21 lutego). Pozyskano z: https://www.fwf.ac.at/de/ueber-den-fwf/ leitbild

Ideen Lab 4.0. (2021, 21 lutego). Pozyskano z: https://www.ffg.at/ideenlab

Impact Innovation - Förderung, Bedingungen. (2021, 21 lutego). Pozyskano z: https://www.ffg.at/programm/impactinnovation

Innovation im Unternehmenssektor. (2021, 21 lutego). Pozyskano z: https://www.statistik.at/web_de/ statistiken/energie_umwelt_innovation_mobilitaet/forschung_und_innovation/innovation_im_ unternehmenssektor/index.html

Innovationsscheck mit Selbstbehalt. (2021, 21 lutego). Pozyskano z: https://www.ffg.at/programme/ InnovationsscheckmitSelbstbehalt

Jasiński, A.H. (2014). Innowacyjność w gospodarce Polski. Modele, bariery, instrumenty wsparcia. Warszawa: Wydawnictwo Naukowe Wydziału Zarządzania Uniwersytetu Warszawskiego.

Kalinowski, T. (2010). Innowacyjność przedsiębiorstw a systemy zarządzania jakościq. Warszawa: Wolters Kluwer business.

Portal FWF. (2021, 21 lutego). https://www.fwf.ac.at

Portal Staatpreis Innovation. (2021, 21 lutego). https://www.staatspreis.at

Prystrom, J. (2012). Innowacje w procesie rozwoju gospodarczego. Istota i uwarunkowania. Warszawa: Difin.

Rankingi innowacyjności 2019. (2021, 21 lutego). Pozyskano z: https://ec.europa.eu/poland/news/ 190617_innovations_pl

Staatspreis Innovation. (2021, 21 lutego). Pozyskano z: https://www.aws.at/staatspreis-innovation

Studia $w$ Austrii. (2021, 21 lutego). Pozyskano z: https://www.eurodesk.pl/mobilnosc/eurostudia/ studia-w-austrii

Szwankowska-Antol, K. (2020). System szkolnictwa w Austrii. Pozyskano z: https://wenedi.eu/pl/poradzimy/system-szkolnictwa-w-austrii-edukacja-w-austrii

Zarys szkolnictwa w Austrii. (2021, 21 lutego). Pozyskano z: https://pracaikariera.e-magnes.pl/artykuly/ austria/szkola/zarys-szkolnictwa-w-austrii 
Robert Majkut, dr, Wyższa Szkoła Bankowa we Wrocławiu. Socjolog gospodarki oraz organizacji i zarządzania, zajmujący się badaniami dotyczącymi przedsiębiorczości, jej uwarunkowań i czynników. Uczestniczył w ponad 10 projektach badawczych, w tym projekcie dotyczącym analizy Strategii rozwoju województwa dolnoślaskiego. Oprócz dorobku naukowego charakteryzuje się osiągnięciami organizacyjnymi, m.in. związanymi z implementacją rozwiązań podnoszących poziom jakości kształcenia stanowiących efekt doświadczeń wyniesionych z Franklin University w Columbus w stanie Ohio w USA.

Robert Majkut, PhD, WSB University in Wroclaw. He is a sociologist of economy and organisation and management, involved in research on entrepreneurship, its conditions and factors. His research output includes participation in 10 research projects, including an analysis for the Development Strategy of the Lower Silesian Voivodship. Apart from his academic achievements, he is characterised by organisational achievements, including those related to the implementation of solutions aimed at improving the quality of education, which are the result of his experience at Franklin University in Columbus, Ohio, USA.

ORCID: https://orcid.org/0000-0002-4181-512

\section{Adres/Address:}

Wyższa Szkoła Bankowa we Wrocławiu

ul. Fabryczna 29-31

53-609 Wrocław, Poland

e-mail: robert.majkut@wsb.wroclaw.pl 